\title{
Halobacillus salsuginis sp. nov., a moderately halophilic bacterium from a subterranean brine
}

\author{
Correspondence \\ Wen-Jun Li \\ wjli@ynu.edu.cn \\ Yi-Guang Chen \\ mchenjsu@yahoo.com.cn
}

\author{
Yi-Guang Chen, ${ }^{1,2}+$ Yu-Oin Zhang, ${ }^{2,3}+$ Zhu-Xiang Liu, ${ }^{1}$ Da-Chun Zhuang, ${ }^{1}$ \\ Hans-Peter Klenk, ${ }^{4}$ Shu-Kun Tang, ${ }^{2}$ Xiao-Long Cui ${ }^{2}$ and Wen-Jun $\mathrm{Li}^{2,5}$
${ }^{1}$ College of Biology and Environmental Sciences, Jishou University, Jishou 416000, PR China
${ }^{2}$ The Key Laboratory for Microbial Resources of the Ministry of Education, PR China, and Laboratory for Conservation and Utilization of Bio-Resources, Yunnan Institute of Microbiology, Yunnan University, Kunming 650091, PR China
${ }^{3}$ Institute of Medicinal Biotechnology, Chinese Academy of Medical Sciences \& Peking Union Medical College, Beijing 100050, PR China
${ }^{4}$ Deutsche Sammlung von Mikroorganismen und Zellkulturen, D-38124 Braunschweig, Germany
${ }^{5}$ Guangdong Key Laboratory of Marine Materia Medica, South China Sea Institute of Oceanology, Chinese Academy of Sciences, Guangzhou 510301, PR China

The genus Halobacillus was proposed by Spring et al. (1996) to accommodate two novel species, Halobacillus litoralis and Halobacillus trueperi, and the transfer of Sporosarcina halophila (Claus et al., 1983) to Halobacillus as Halobacillus halophilus. At the time of writing, the genus comprises 16 recognized species, the three named above plus Halobacillus salinus (Yoon et al., 2003), H. karajensis (Amoozegar et al., 2003), H. locisalis (Yoon et al., 2004), H. aidingensis and $H$. dabanensis (Liu et al., 2005), $H$. yeomjeoni (Yoon et al., 2005), H. campisalis (Yoon et al., 2007), H. profundi and H. kuroshimensis (Hua et al., 2007), H. faecis (An et al., 2007), H. alkaliphilus (Romano et al., 2008), H. mangrovi (Soto-Ramírez et al., 2008) and $H$. seohaensis (Yoon et al., 2008). In a recent study of the

†These authors contributed equally to this work.

The GenBank/EMBL/DDBJ accession number for the 16S rRNA gene sequence of strain JSM $078133^{\top}$ is FJ456889. microbial diversity in the ancient salt deposit of the Xiangli Salt Mine in Hunan Province, China, a moderately halophilic bacterium, designated JSM $078133^{\mathrm{T}}$, was isolated from a subterranean brine sample. Data from the present polyphasic taxonomic study indicate that this strain represents a novel species of the genus Halobacillus.

Strain JSM $078133^{\mathrm{T}}$ was isolated from a subterranean brine sample by plating 1:10 serial dilutions of the sample on Difco marine agar 2216 (MA) supplemented with 5\% (w/v) $\mathrm{NaCl}$ (hereafter MA5) at $30{ }^{\circ} \mathrm{C}$ for 2 weeks. After primary isolation and purification, the isolate was kept either as serial transfers on MA5 slants, or as lyophilized cultures at $4{ }^{\circ} \mathrm{C}$ or deep-frozen at $-80{ }^{\circ} \mathrm{C}$ in Difco marine broth $2216(\mathrm{MB})$ supplemented with $5 \%(\mathrm{w} / \mathrm{v}) \mathrm{NaCl}$ and $20 \%(\mathrm{v} / \mathrm{v})$ glycerol. Unless indicated otherwise, morphological and physiological studies were performed with cells grown on MA5 at $\mathrm{pH} 7.5$ and $30{ }^{\circ} \mathrm{C}$. Two reference strains, H. campisalis KCTC $13144^{\mathrm{T}}$ and $H$. alkaliphilus DSM 
$18525^{\mathrm{T}}$, were obtained from the KCTC (Korean Collection for Type Cultures) and the DSMZ (Deutsche Sammlung von Mikroorganismen und Zellkulturen), respectively. Cell morphology was examined by using light microscopy (model BH 2; Olympus). Gram staining was carried out by using the standard Gram reaction combined with the $\mathrm{KOH}$ lysis method (Gregersen, 1978). Flagella and endospores were examined according to the methods of Leifson and Schaeffer-Fulton, respectively (Smibert \& Krieg, 1994). Growth was tested at various temperatures $\left(5-55{ }^{\circ} \mathrm{C}\right.$, at increments of $\left.5{ }^{\circ} \mathrm{C}\right)$ and different $\mathrm{pH}(5.0-11.0$, at increments of $0.5 \mathrm{pH}$ units) in $\mathrm{MB}$ supplemented with $5 \%(\mathrm{w} / \mathrm{v}) \mathrm{NaCl}$ and on $\mathrm{MA} 5$ plates. For $\mathrm{pH}$ experiments, the buffer solutions described by Chen et al. (2007) were used. Growth at different total salt contents $[0,0.1$ and $0.5 \%(\mathrm{w} / \mathrm{v})$, and $1-30 \%(\mathrm{w} / \mathrm{v})$ at increments of $1 \%$ ] was determined with both $\mathrm{MB}$ and MA prepared according to the formula of Atlas (1993). The concentration of all salts contained in $\mathrm{MB}$ or $\mathrm{MA}$ was changed (proportions maintained) as an integer in the salt-response experiment. In order to determine the specific ionic requirement of the new isolate, growth at different concentrations $(0.1,0.5,1$ and $3 \%, w / v)$ of $\mathrm{NaCl}$ or $\mathrm{MgCl}_{2} \cdot 6 \mathrm{H}_{2} \mathrm{O}$ or the mixture of $\mathrm{NaCl}$ plus $\mathrm{MgCl}_{2} \cdot 6 \mathrm{H}_{2} \mathrm{O}(1: 1)$ was also tested in $\mathrm{MB}$ and on MA with all other trace salts omitted. Methyl red and Voges-Proskauer tests, $\mathrm{H}_{2} \mathrm{~S}$ production from L-cysteine, hydrolysis of aesculin, indole production, nitrate and nitrite reduction, and phenylalanine deaminase, lysine decarboxylase, ornithine decarboxylase and urease were determined as recommended by Smibert \& Krieg (1994). Hydrolysis of casein, cellulose, DNA, gelatin, hypoxanthine, starch, Tweens (20, 40, 60 and 80), tyrosine and xanthine was determined as described by Cowan \& Steel (1965). Determination of acid production from carbohydrates, as well as utilization of carbon and nitrogen sources, was performed as recommended by Ventosa et al. (1982). Motility, growth under anaerobic conditions, antibiotic susceptibility, and catalase and oxidase activities were determined as described by Chen et al. (2007). Other enzymic activities were tested by using API ZYM systems (bioMérieux) according to the manufacturer's instructions with $7.5 \%(\mathrm{w} / \mathrm{v}) \mathrm{NaCl}$. The morphological, physiological and biochemical characteristics of strain JSM $078133^{\mathrm{T}}$ are summarized in the species description below and in Table 1 .

Genomic DNA was isolated according to Hopwood et al. (1985) and the G $+\mathrm{C}$ content was determined by using the HPLC method (Mesbah et al., 1989). The 16S rRNA gene was amplified and sequenced as described by Cui et al. (2001). The resulting 16S rRNA gene sequence of strain JSM $078133^{\mathrm{T}}$ was compared with sequences obtained from public databases (GenBank/EMBL/DDBJ) to find the most closely related species. Phylogenetic analyses were performed by using the software package MEGA version 4.1 (Tamura et al., 2007) after multiple alignment of the sequence data with CLUSTAL_X (Thompson et al., 1997). Distances were calculated by using distance options according to Kimura's two-parameter model (Kimura,
1980) and clustering was performed with the neighbourjoining method (Saitou \& Nei, 1987). Maximum-parsimony (Kluge \& Farris, 1969) and minimum-evolution (Felsenstein, 1997) trees (not shown) were generated by means of methods contained within the software package MEGA version 4.1 (Tamura et al., 2007). Bootstrap analysis was used to evaluate the tree topology of the neighbourjoining data by means of 1000 resamplings (Felsenstein, 1985). DNA-DNA hybridization experiments were carried out by using photobiotin-labelled probes in microplate wells as described by Ezaki et al. (1989).

The DNA G + C content of strain JSM $078133^{\mathrm{T}}$ was $42.2 \mathrm{~mol} \%$. The almost-complete $16 \mathrm{~S}$ rRNA gene sequence (1541 bp) was determined. Phylogenetic analyses based on $16 \mathrm{~S}$ rRNA gene sequences revealed that strain JSM $078133^{\mathrm{T}}$ belongs to the genus Halobacillus, and was related most closely to the type strains of $H$. campisalis ( $97.1 \%$ sequence similarity), $H$. alkaliphilus $(97.0 \%)$ and $H$. yeomjeoni $(96.8 \%)$. Levels of $16 \mathrm{~S}$ rRNA gene sequence similarity between strain JSM $078133^{\mathrm{T}}$ and the type strains of other recognized Halobacillus species were in the range $96.7 \%$ ( $H$. dabanensis) to $94.8 \%$ ( $H$. kuroshimensis). In the neighbour-joining phylogenetic tree, however, strain JSM $078133^{\mathrm{T}}$ and the type strains of $H$. campisalis, $H$. alkaliphilus, $H$. halophilus (96.4\% 16S rRNA gene sequence similarity) and $H$. seohaensis (95.9\%) formed a subcluster separate from other recognized Halobacillus species, in which strain JSM $078133^{\mathrm{T}}$ occupied a distinct clade (Fig. 1).

Amino acids of whole-cell hydrolysates were analysed as described by Hasegawa et al. (1983). Isoprenoid quinones were analysed by HPLC as described by Groth et al. (1996). Fatty acids were determined according to Sasser (1990) by using the Microbial Identification System (MIDI; Microbial ID) with cells grown in MB supplemented with $5 \%(\mathrm{w} / \mathrm{v}) \mathrm{NaCl}$ in flasks on a rotary shaker (about 180 r.p.m.) at $30{ }^{\circ} \mathrm{C}$ for 3 days. Chemotaxonomic data for strain JSM $078133^{\mathrm{T}}$ were consistent with its assignment to the genus Halobacillus. Strain JSM $078133^{\mathrm{T}}$ possessed a cell-wall type based on meso-diaminopimelic acid and contained menaquinone 7 (MK-7; 98.5\%) as the predominant respiratory quinone with MK-8 (1.5\%) present in trace amounts. The major fatty acids of strain JSM $078133^{\mathrm{T}}$ were anteiso- $\mathrm{C}_{15: 0}(50.5 \%$ of the total $)$, anteiso- $\mathrm{C}_{17: 0}$ $(18.6 \%)$ and iso- $\mathrm{C}_{15: 0}(10.1 \%)$; iso- $\mathrm{C}_{14: 0}(1.3 \%)$, iso$\mathrm{C}_{16: 0}(6.7 \%), \mathrm{C}_{15: 0}(1.2 \%), \mathrm{C}_{16: 0}(4.4 \%), \mathrm{C}_{18: 0}(1.3 \%)$ and summed feature 4 (iso- $\mathrm{C}_{17: 1} \mathrm{I}$ and/or anteiso- $\mathrm{C}_{17: 1} \mathrm{~B}$; $1.2 \%)$ were present in minor amounts, and $\mathrm{C}_{16: 1} \omega 7 c$ alcohol, $\mathrm{C}_{17: 1} \omega 10 c$ and summed feature 5 (anteiso- $\mathrm{C}_{18: 0}$ and/or $\left.\mathrm{C}_{18: 2} \omega 6,9 c\right)$ were detected at a level $<1 \%$. This fatty acid profile was similar to those of recognized Halobacillus species, although there were differences in the proportions of some components, probably because of differences in cultivation conditions and extraction procedures (Liu et al., 2005; Yoon et al., 2005, 2007, 2008).

The results of phylogenetic analysis, and morphological and chemotaxonomic investigations supported the view 
Table 1. Characteristics used to distinguish strain JSM $078133^{\top}$ from phylogenetically related Halobacillus species

Taxa: 1, strain JSM $078133^{\mathrm{T}}$ (H. salsuginis sp. nov.); 2, H. campisalis (data from Yoon et al., 2007); 3, H. alkaliphilus (Romano et al., 2008); 4, H. yeomjeoni (Yoon et al., 2005); 5, H. halophilus (Claus et al., 1983; Spring et al., 1996; Romano et al., 2008); 6, H. seohaensis (Yoon et al., 2008). +, Positive; -, negative; V, variable; ND, no data available. All taxa are positive for catalase and oxidase activity but negative for anaerobiosis and urease.

\begin{tabular}{|c|c|c|c|c|c|c|}
\hline Characteristic & 1 & 2 & 3 & 4 & 5 & 6 \\
\hline Colony colour & Cream & Light yellow & Pale orange-yellow & Light yellow & Orange & Yellowish white \\
\hline Gram staining & + & $+(\mathrm{v})$ & + & $+(\mathrm{v})$ & + & $+(\mathrm{v})$ \\
\hline Cell morphology & Rods & Cocci/ovoid & Cocci & $\begin{array}{c}\text { Rods/long } \\
\text { filamentous rods }\end{array}$ & Cocci/ovoid & Rods \\
\hline Flagellation & Peritrichous & Peritrichous & ND & Single & Single/peritrichous & Single \\
\hline Spore position $\dagger$ & ST & $\mathrm{C}$ & ND & $\mathrm{C} / \mathrm{ST}$ & $\mathrm{C} / \mathrm{L}$ & $\mathrm{C} / \mathrm{ST}$ \\
\hline Temperature range $\left({ }^{\circ} \mathrm{C}\right)$ & $10-45$ & $4-41$ & $25-50$ & $15-48$ & $15-40$ & $4-38$ \\
\hline $\mathrm{pH}$ optimum & 7.5 & $7.0-8.0$ & 9.0 & $7-8$ & 7.2 & $7.0-8.0$ \\
\hline $\mathrm{NaCl}$ range $(\%, w / v)$ & $1-23$ & $0-22$ & $5-25$ & $0.5-21$ & $2-20$ & $1-12$ \\
\hline $\mathrm{NaCl}$ optimum $(\%, w / v)$ & $5-10$ & 8 & 10 & $3-5$ & 10 & 8 \\
\hline \multicolumn{7}{|l|}{ Hydrolysis of: } \\
\hline Tween 80 & - & - & ND & + & - & - \\
\hline Tyrosine & - & - & + & - & - & - \\
\hline \multicolumn{7}{|l|}{ Acid production from: } \\
\hline D-Fructose & - & + & + & - & - & - \\
\hline D-Glucose & + & + & + & + & - & - \\
\hline D-Galactose & - & + & - & - & - & - \\
\hline D-Mannitol & - & - & ND & + & - & + \\
\hline Maltose & + & - & + & + & - & - \\
\hline Sucrose & + & + & + & + & - & + \\
\hline Trehalose & + & + & + & + & - & + \\
\hline D-Xylose & - & - & + & - & - & + \\
\hline
\end{tabular}

${ }^{\star}$ E, Ellipsoidal; S, spherical.

†C, Central; L, lateral; T, terminal; ST, subterminal.

末D-Asp, D-asparagine; meso-DAP, meso-diaminopimelic acid; L-Orn, L-ornithine.

that strain JSM $078133^{\mathrm{T}}$ should be assigned to the genus Halobacillus. However, it could be distinguished from its closest phylogenetic relatives in the genus on the basis of several phenotypic characteristics (Table 1). To establish the precise taxonomic position of strain JSM $078133^{\mathrm{T}}$, DNA-DNA hybridization experiments were performed between the novel isolate and the type strains of $H$. campisalis and $H$. alkaliphilus. Levels of DNA-DNA relatedness between strain JSM $078133^{\mathrm{T}}$ and the type strains of these two species were 13.4 and $10.2 \%$, respectively, values that are well below the threshold value of $70 \%$ recommended by Wayne et al. (1987) for assigning strains to the same species. Therefore, on the basis of the data from the present polyphasic taxonomic study, strain
JSM $078133^{\mathrm{T}}$ should be placed in the genus Halobacillus as a member of a novel species, for which we propose the name Halobacillus salsuginis sp. nov.

\section{Description of Halobacillus salsuginis sp. nov.}

Halobacillus salsuginis (sal.su'gi.nis. L. gen. fem. n. salsuginis of/from brine).

Cells are Gram-positive, moderately halophilic, catalaseand oxidase-positive, aerobic rods, approximately 0.5$0.9 \mu \mathrm{m}$ wide and $1.5-3.0 \mu \mathrm{m}$ long, occurring singly, in pairs or in short chains. Motile by means of peritrichous flagella. Cells bear ellipsoidal endospores that lie in subterminal swollen sporangia. Colonies are cream- 


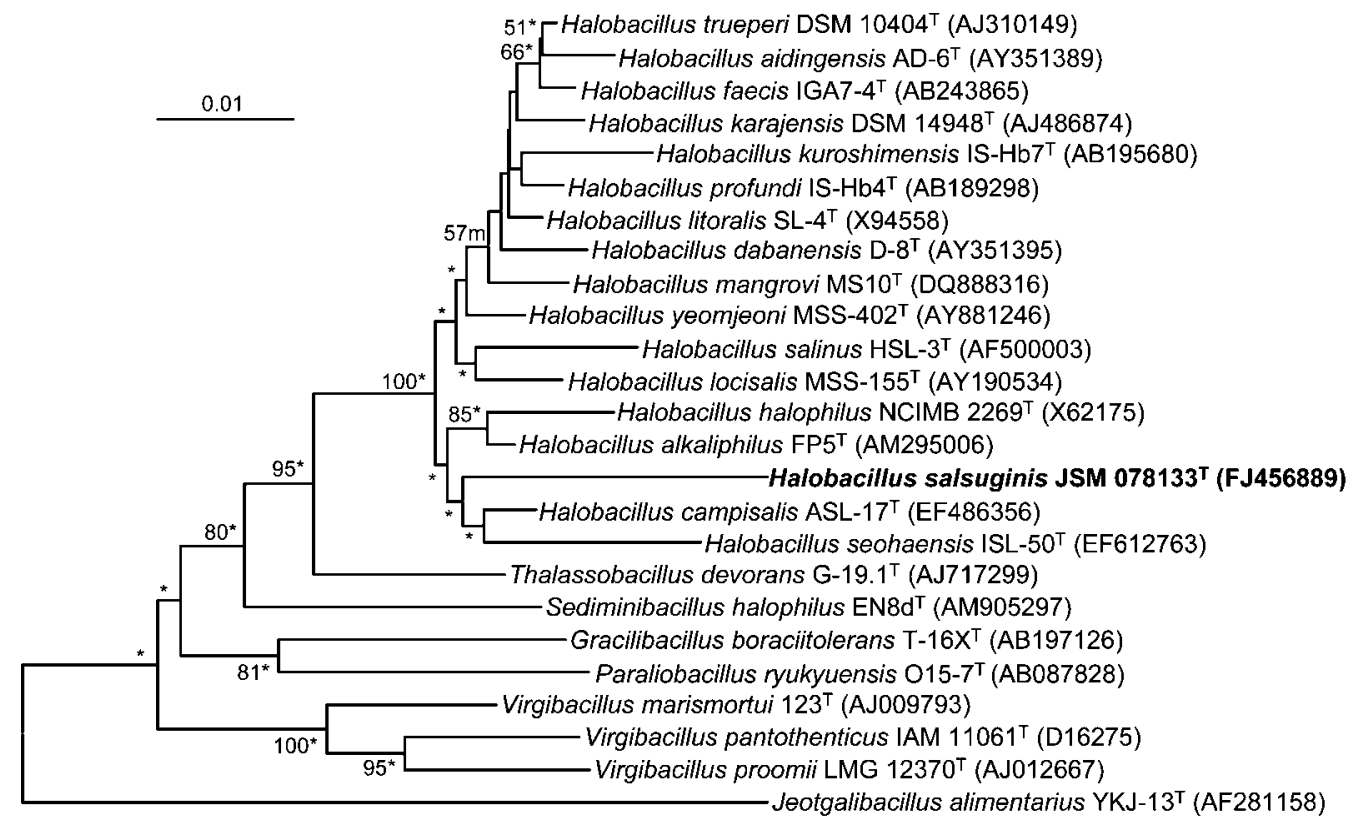

Fig. 1. Phylogenetic tree based on $16 \mathrm{~S}$ rRNA gene sequence analysis and constructed by using the neighbour-joining method showing the position of strain JSM $078133^{\top}$ among related taxa. ' $\mathrm{m}$ ' indicates a branch that was also found with the minimumevolution (Felsenstein, 1997) method; asterisks indicate branches that were also recovered using the minimum-evolution and maximum-parsimony (Kluge \& Farris, 1969) algorithms. Numbers at nodes indicate bootstrap values (>50\%) based on a neighbour-joining analysis of 1000 resampled datasets. Bar, 1 substitution per 100 nt.

coloured, of low convexity and semi-translucent with circular/slightly irregular margins, and are 1-2 $\mathrm{mm}$ in diameter after incubation for $3-5$ days at $30{ }^{\circ} \mathrm{C}$ on MA5. Growth occurs with 1-23\% (w/v) total salts (optimum, 5$10 \%$ ) and at $\mathrm{pH} 6.0-10.0$ (optimum, $\mathrm{pH} 7.5$ ) and 10$45{ }^{\circ} \mathrm{C}$ (optimum, $30{ }^{\circ} \mathrm{C}$ ). $\mathrm{Na}^{+}$and $\mathrm{Mg}^{2+}$ ions are required for growth. Positive for nitrate reduction and phenylalanine deaminase, but negative for methyl red and VogesProskauer tests, nitrite reduction, $\mathrm{H}_{2} \mathrm{~S}$ and indole production, and lysine decarboxylase, ornithine decarboxylase and urease. Aesculin, DNA, gelatin, starch and Tween 40 are hydrolysed, but casein, cellulose, hypoxanthine, Tweens 20 , 60 and 80, tyrosine and xanthine are not. Acids are produced from D-arabitol, D-glucose, maltose, sucrose and trehalose, but not from adonitol, L-arabinose, cellobiose, dulcitol, D-fructose, D-galactose, glycerol, myo-inositol, Dlactose, D-mannitol, D-mannose, melezitose, melibiose, raffinose, L-rhamnose, D-ribose, D-salicin, D-sorbitol or Dxylose. The following compounds are utilized as sole source of carbon and energy or sole source of carbon, nitrogen and energy: L-arabinose, dextrin, D-fructose, D-glucose, maltose, raffinose, sucrose, adonitol, D-sorbitol, L-alanine, L-asparagine and L-serine. The following are not utilized: cellobiose, D-galactose, D-lactose, D-mannose, melezitose, melibiose, L-rhamnose, D-ribose, D-salicin, trehalose, Dxylose, D-arabitol, glycerol, myo-inositol, D-mannitol, acetate, butyrate, citrate, gluconate, propionate, succinate, L-arginine, L-glutamic acid, D-glycine, L-histidine, hydroxyL-proline, L-isoleucine, L-leucine, L-methionine, L-proline and L-valine. Constitutive enzymes expressed are alkaline phosphatase, esterase (C4) and esterase lipase (C8), but not acid phosphatase, $\alpha$-chymotrypsin, cystine arylamidase, $\alpha$ fucosidase, $\alpha$-galactosidase, $\beta$-galactosidase, $N$-acetyl- $\beta$ glucosaminidase, $\alpha$-glucosidase, $\beta$-glucosidase, $\beta$-glucuronidase, leucine arylamidase, lipase (C14), $\alpha$-mannosidase, naphthol-AS-BI-phosphohydrolase, trypsin or valine arylamidase. Susceptible to ( $\mu \mathrm{g}$ per disc): ampicillin (30), carbenicillin (30), chloramphenicol (30), gentamicin (10), kanamycin (30), lincomycin (2), rifampicin (5) and streptomycin (10), but not to nalidixic acid (20), nitrofurantoin (30), novobiocin (30), polymixin B (30), tetracycline (30) or tobramycin (10). meso-Diaminopimelic acid is present in the cell-wall peptidoglycan as the diagnostic diamino acid. Possesses MK-7 as the predominant menaquinone. Major fatty acids are anteiso- $\mathrm{C}_{15: 0}$, anteiso- $\mathrm{C}_{17: 0}$ and iso- $\mathrm{C}_{15: 0}$. The DNA G $+\mathrm{C}$ content of the type strain is $42.2 \mathrm{~mol} \%$.

The type strain, JSM $078133^{\mathrm{T}}\left(=\mathrm{DSM} 21185^{\mathrm{T}}=\mathrm{KCTC}\right.$ $\left.13236^{\mathrm{T}}\right)$, was isolated from a subterranean brine sample collected from the Xiangli Salt Mine in Hunan Province, China.

\section{Acknowledgements}

This work was supported by grants from the National Natural Science Foundation of China (NSFC) (30660004, 30860002, 30860013), Jishou University (jsdxkyzz200811, 07JD004), the Ministry of 
Science and Technology, PR China (2006BAE01A01-9, 863 Program, no. 2007AA021306) and the Yunnan Provincial Sciences and Technology Department (2005PY01-1, 2006C0006M, 2006C0004M). W.-J. L. was supported by the Program for New Century Excellent Talents in University. We are grateful to Mr Huai-Dong Xiao and $\mathrm{Mr}$ Ke Huang for their excellent technical assistance.

\section{References}

Amoozegar, M. A., Malekzadeh, F., Malik, K. A., Schumann, P. \& Spröer, C. (2003). Halobacillus karajensis sp. nov., a novel moderate halophile. Int J Syst Evol Microbiol 53, 1059-1063.

An, S.-Y., Kanoh, K., Kasai, H., Goto, K. \& Yokota, Y. (2007). Halobacillus faecis sp. nov., a spore-forming bacterium isolated from a mangrove area on Ishigaki Island, Japan. Int J Syst Evol Microbiol 57, 2476-2479.

Atlas, R. M. (1993). Handbook of Microbiological Media. Edited by L. C. Parks. Boca Raton, FL: CRC Press.

Chen, Y.-G., Cui, X.-L., Pukall, R., Li, H.-M., Yang, Y.-L., Xu, L.-H., Wen, M.-L., Peng, Q. \& Jiang, C.-L. (2007). Salinicoccus kunmingensis sp. nov., a moderately halophilic bacterium isolated from a salt mine in Yunnan, south-west China. Int J Syst Evol Microbiol 57, 2327-2332.

Claus, D., Fahmy, F., Rolf, H. J. \& Tosunoglu, N. (1983). Sporosarcina halophila sp. nov., an obligate, slightly halophilic bacterium from salt marsh soils. Syst Appl Microbiol 4, 496-506.

Cowan, S. T. \& Steel, K. J. (1965). Manual for the Identification of Medical Bacteria. London: Cambridge University Press.

Cui, X.-L., Mao, P.-H., Zeng, M., Li, W.-J., Zhang, L.-P., Xu, L.-H. \& Jiang, C.-L. (2001). Streptomonospora salina gen. nov., sp. nov., a new member of the family Nocardiopsaceae. Int J Syst Evol Microbiol 51, 357-363.

Ezaki, T., Hashimoto, Y. \& Yabuuchi, E. (1989). Fluorometric deoxyribonucleic acid-deoxyribonucleic acid hybridization in microdilution wells as an alternative to membrane filter hybridization in which radioisotopes are used to determine genetic relatedness among bacterial strains. Int J Syst Bacteriol 39, 224-229.

Felsenstein, J. (1985). Confidence limits on phylogenies: an approach using the bootstrap. Evolution 39, 783-791.

Felsenstein, J. (1997). An alternative least-squares approach to inferring phylogenies from pairwise distances. Syst Biol 46, 101-111.

Gregersen, T. (1978). Rapid method for distinction of Gram-negative from Gram-positive bacteria. Eur J Appl Microbiol Biotechnol 5, 123-127.

Groth, I., Schumann, P., Weiss, N., Martin, K. \& Rainey, F. A. (1996). Agrococcus jenensis gen. nov., sp. nov., a new genus of actinomycetes with diaminobutyric acid in the cell wall. Int J Syst Bacteriol 46, 234239.

Hasegawa, T., Takizawa, M. \& Tanida, S. (1983). A rapid analysis for chemical grouping of aerobic actinomycetes. J Gen Appl Microbiol 29, 319-322.

Hopwood, D. A., Bibb, M. J., Chater, K. F., Kieser, T., Bruton, C. J., Kieser, H. M., Lydiate, D. J., Smith, C. P. \& Ward, J. M. (1985). Preparation of chromosomal, plasmid and phage DNA. In Genetic Manipulation of Streptomyces: a Laboratory Manual, pp. 79-80. Norwich, UK: John Innes Foundation.

Hua, N.-P., Kanekiyo, A., Fujikura, K., Yasuda, H. \& Naganuma, T. (2007). Halobacillus profundi sp. nov. and Halobacillus kuroshimensis sp. nov., moderately halophilic bacteria isolated from a deep-sea methane cold seep. Int J Syst Evol Microbiol 57, 1243-1249.

Kimura, M. (1980). A simple method for estimating evolutionary rates of base substitutions through comparative studies of nucleotide sequences. J Mol Evol 16, 111-120.
Kluge, A. G. \& Farris, F. S. (1969). Quantitative phyletics and the evolution of anurans. Syst Zool 18, 1-32.

Liu, W. Y., Zeng, J., Wang, L., Dou, Y. T. \& Yang, S. S. (2005). Halobacillus dabanensis sp. nov. and Halobacillus aidingensis sp. nov., isolated from salt lakes in Xinjiang, China. Int J Syst Evol Microbiol 55, 1991-1996.

Mesbah, M., Premachandran, U. \& Whitman, W. B. (1989). Precise measurement of the $\mathrm{G}+\mathrm{C}$ content of deoxyribonucleic acid by highperformance liquid chromatography. Int J Syst Bacteriol 39, 159-167.

Romano, I., Finore, L., Nicolaus, G., Huertas, F. J., Lama, L., Nicolaus, B. \& Poli, A. (2008). Halobacillus alkaliphilus sp. nov., a halophilic bacterium isolated from a salt lake in Fuente de Piedra, southern Spain. Int J Syst Evol Microbiol 58, 886-890.

Saitou, N. \& Nei, M. (1987). The neighbor-joining method: a new method for reconstructing phylogenetic trees. Mol Biol Evol 4, 406-425.

Sasser, M. (1990). Identification of bacteria by gas chromatography of cellular fatty acids, MIDI Technical Note 101. Newark, DE: MIDI Inc.

Smibert, R. M. \& Krieg, N. R. (1994). Phenotypic characterization. In Methods for General and Molecular Bacteriology, pp. 607-654. Edited by P. Gerhardt, R. G. E. Murray, W. A. Wood \& N. R. Krieg. Washington, DC: American Society for Microbiology.

Soto-Ramírez, N., Sánchez-Porro, C., Rosas-Padilla, S., Almodóvar, K., Jiménez, G., Machado-Rodríguez, M., Zapata, M., Ventosa, A. \& Montalvo-Rodríguez, R. (2008). Halobacillus mangrovi sp. nov., a moderately halophilic bacterium isolated from the black mangrove Avicennia germinans. Int J Syst Evol Microbiol 58, 125-130.

Spring, S., Ludwig, W., Marquez, M. C., Ventosa, A. \& Schleifer, K.-H. (1996). Halobacillus gen. nov., with descriptions of Halobacillus litoralis sp. nov. and Halobacillus trueperi sp. nov., and transfer of Sporosarcina halophila to Halobacillus halophilus comb. nov. Int J Syst Bacteriol 46, 492-496.

Tamura, K., Dudley, J., Nei, M. \& Kumar, S. (2007). MEGA4: molecular evolutionary genetic analysis (MEGA) software version 4.0. Mol Biol Evol 24, 1596-1599.

Thompson, J. D., Gibson, T. J., Plewniak, F., Jeanmougin, F. \& Higgins, D. G. (1997). The CLUSTAL_X windows interface: flexible strategies for multiple sequence alignment aided by quality analysis tools. Nucleic Acids Res 25, 4876-4882.

Ventosa, A., Quesada, E., Rodriguez-Valera, F., Ruiz-Berraquero, F. \& Ramos-Cormenzana, A. (1982). Numerical taxonomy of moderately halophilic Gram-negative rods. J Gen Microbiol 128, 1959-1968.

Wayne, L. G., Brenner, D. J., Colwell, R. R., Grimont, P. A. D., Kandler, O., Krichevsky, M. I., Moore, L. H., Moore, W. E. C., Murray, R. G. E. \& other authors (1987). International Committee on Systematic Bacteriology. Report of the ad hoc committee on reconciliation of approaches to bacterial systematics. Int J Syst Bacteriol 37, 463-464.

Yoon, J.-H., Kang, K. H. \& Park, Y.-H. (2003). Halobacillus salinus sp. nov., isolated from a salt lake on the coast of the East Sea in Korea. Int $J$ Syst Evol Microbiol 53, 687-693.

Yoon, J.-H., Kang, K. H., Oh, T.-K. \& Park, Y.-H. (2004). Halobacillus locisalis sp. nov., a halophilic bacterium isolated from a marine solar saltern of the Yellow Sea in Korea. Extremophiles 8, 23-28.

Yoon, J.-H., Kang, S.-J., Lee, C.-H., Oh, H. W. \& Oh, T.-K. (2005). Halobacillus yeomjeoni sp. nov., isolated from a marine solar saltern in Korea. Int J Syst Evol Microbiol 55, 2413-2417.

Yoon, J.-H., Kang, S.-J., Jung, Y.-T. \& Oh, T.-K. (2007). Halobacillus campisalis sp. nov., containing meso-diaminopimelic acid in the cellwall peptidoglycan, and emended description of the genus Halobacillus. Int J Syst Evol Microbiol 57, 2021-2025.

Yoon, J.-H., Kang, S.-J. \& Oh, T.-K. (2008). Halobacillus seohaensis sp. nov., isolated from a marine solar saltern in Korea. Int J Syst Evol Microbiol 58, 622-627. 